\title{
Irrational fixed dose combinations in Nepal: Need for intervention
}

Poudel A $\mathbf{1}^{1}$, Palaian $\mathrm{S}^{2}$, Shankar PR ${ }^{3}$, Jayasekera $\mathbf{J}^{4}$, Izham MIM ${ }^{5}$

${ }^{1}$ Hospital and Clinical Pharmacist, Drug Information and Pharmacovigilance Center, Manipal Teaching Hospital, Pokhara, Nepal, ${ }^{2}$ Assistant Professor, Department of Pharmacy/ Pharmacology, Manipal College of Medical Sciences, Pokhara, Nepal, ${ }^{3}$ Department of Pharmacology and Therapeutics, KIST Medical College, Lalitpur, Nepal, ${ }^{4}$ Project coordinator, Health Action International, Colombo, Sri Lanka, ${ }^{5}$ Associate Professor, Discipline of Social and Administrative Pharmacy, School of Pharmaceutical Sciences, Universiti Sains Malaysia, Penang, Malaysia

\begin{abstract}
A large proportion of drugs available are of little importance in terms of fulfilling primary healthcare needs. Combination drugs increase the risk of side effects, lead to an ineffective dosage and liability to abuse and may also needlessly increase the cost. Drug combinations make it more difficult to find the causative agent responsible for the adverse reactions. In many cases their stability is doubtful, reducing the efficacy of many preparations. The Fifteenth WHO model list of essential medicines (March 2007) contains only 25 approved fixed dose combinations, whereas in Nepal, there are innumerable examples of irrational drug combinations, which are easily available and can be bought even without a prescription. A system of screening the drug combinations that are already licensed and available in the market is implemented in many developed and developing countries. Rational combinations can be of immense help to the health care system. These combinations may improve the quality of life for many and increase compliance. But irrational fixed dose combination products can be equally harmful.
\end{abstract}

Key words: Adverse drug reaction, Combination drugs, Fixed dose combination, Irrational drug use, Nepal

$\mathrm{T}_{\mathrm{s}}$ reating a particular ailment with effective, safe and good quality drugs is the basic aim of drug therapy ${ }^{1}$. It is well documented that safe and effective drug therapy is possible only when patients are well informed about the medications and their use. Irrational drug use can lead to reduction in quality of drug therapy, increased risk of side effects, drug resistance etc ${ }^{2}$. Large proportions of the drugs that are available in the market are of little importance in terms of providing primary healthcare. Prescribing more than one drug for a particular ailment has become a very common practice among physicians. Whether the pharmaceutical manufacturers make the fixed dose combinations (FDCs) because of demand by the physician or physician prescribes multiple drugs because these dosage forms are easily available is a highly debatable issue ${ }^{1}$.

More than one-third of all the new drug products introduced worldwide during the last decade were fixed dose combination (FDC) preparations. The trend varies from country to country. In Japan, only 10 percent of the new products were FDCs, whereas, in European countries like Spain, it was up to 56 percent ${ }^{1}$. However, such statistical data are not available for the developing countries, but there seems to be a trend towards increasing production and prescription of FDCs. FDCs are available for the treatment of various ailments ranging from nutritional deficiency to cardiovascular diseases. Some combination products may improve the quality of life for many patients. Such combinations (for example, antitubercular and antiretroviral combinations) are essential for many diseases. Many FDC preparations comprise vitamins, cough suppressants, anti-diarrheals, iron preparations, antacids, analgesics and tonics ${ }^{1}$.

There are many popular FDCs in the Nepalese pharmaceutical market, which have flourished in the last few years. A system of screening the drug combinations that are already licensed and available in the market is implemented in many developed and developing countries ${ }^{1}$. Medical experts worldwide have expressed serious concerns over the increased marketing of drug combinations by pharmaceutical companies, particularly in the developing countries ${ }^{3}$. Most FDCs can impose unnecessary financial burden, increased adverse effects, as well as hospitalization, and decreased quality of life ${ }^{1}$.

\footnotetext{
Correspondence

Arjun Poudel

Hospital and Clinical Pharmacist

Drug Information and Pharmacovigilance Center

Manipal Teaching Hospital

Pokhara, Nepal.

E-mail: poudelarjaan@gmail.com
} 


\section{What are Fixed Dose Combinations?}

A fixed dose combination refers to the combination of two or more drugs in a single pharmaceutical formulation. According to WHO expert committee on specifications for pharmaceutical preparations $\left(39^{\text {th }}\right.$ report, 2005) a FDC can be defined as follows:

A combination of two or more actives in a fixed ratio of doses. This term is used generically to mean a particular combination of actives irrespective of the formulation or brand. It may be administered as single entity products given concurrently or as a finished pharmaceutical product $^{4}$. Due to many reasons the use of FDCs are very common worldwide. But many times the rational behind these FDCs becomes questionable. The lists of FDCs that are included in the WHO essential drug list are presented in Table 1.

Table 1: List of FDCs included in the WHO essential drug list- $15^{\text {th }}$ Edition (March 2007) ${ }^{5}$

\begin{tabular}{|c|c|c|c|}
\hline S. $\mathbf{N}$. & Drugs & Form & Strength \\
\hline 1 & Neomycin + Bacitracin & Ointment & $5 \mathrm{mg}+500 \mathrm{IU}$ \\
\hline 2 & Amoxicillin + Clavulanic acid & Tablet & $500 \mathrm{mg}+125 \mathrm{mg}$ \\
\hline 3 & Imipenem + Cilastatin & Injection & $250 \mathrm{mg}+250 \mathrm{mg}$ \\
\hline 4 & Sulfamethoxazole + Trimethoprim & $\begin{array}{l}\text { Tablet } \\
\text { Oral } \\
\text { Liquid }\end{array}$ & $\begin{array}{l}100 \mathrm{mg}+20 \mathrm{mg} \\
400 \mathrm{mg}+80 \mathrm{mg} \\
200 \mathrm{mg}+40 \mathrm{mg} / 15 \mathrm{ml}\end{array}$ \\
\hline 5 & Sulfamethoxazole + Trimethoprim & Injection & $\begin{array}{l}80 \mathrm{mg}+16 \mathrm{mg} / \mathrm{ml} \\
\text { (in } 5 \mathrm{ml} \text { ampoule) }\end{array}$ \\
\hline 6 & Isoniazid + Ethambutol & Tablet & $150 \mathrm{mg}+400 \mathrm{mg}$ \\
\hline 7 & Rifampicin + Isoniazid & Tablet & $\begin{array}{l}150 \mathrm{mg}+75 \mathrm{mg} \\
300 \mathrm{mg}+150 \mathrm{mg}\end{array}$ \\
\hline 8 & Rifampicin + Isoniazid + Pyrazinamide & Tablet & $150 \mathrm{mg}+75 \mathrm{mg}+400 \mathrm{mg}$ \\
\hline 9 & Rifampicin+ Isoniazid+ Ethambutol & Tablet & $150 \mathrm{mg}+75 \mathrm{mg}+275 \mathrm{mg}$ \\
\hline 10 & Benzoic acid + Salicylic acid & Ointment & $6 \%+3 \%(\mathrm{w} / \mathrm{w})$ \\
\hline 11 & Ethinylestradiol + Levonorgestrel & Tablet & $30 \mu \mathrm{g}+150 \mu \mathrm{g}$ \\
\hline 12 & Rifampicin + Isoniazid + Ethambutol + Pyrazinamide & Tablet & $150 \mathrm{mg}+75 \mathrm{mg}+275 \mathrm{mg}+400 \mathrm{mg}$ \\
\hline 13 & Ethinylestradiol + Norethisterone & Tablet & $35 \mu \mathrm{g}+1 \mathrm{mg}$ \\
\hline 14 & Levodopa + Carbidopa & Tablet & $100 \mathrm{mg}+10 \mathrm{mg} 250 \mathrm{mg}+25 \mathrm{mg}$ \\
\hline 15 & Ferrous salt + Folic acid & Tablet & $60 \mathrm{mg}+400 \mu \mathrm{g}$ \\
\hline 16 & Sulfadoxine + Pyrimethamine & Tablet & $500 \mathrm{mg}+25 \mathrm{mg}$ \\
\hline 17 & Lidocaine + Epinephrine & Injection & 1 or $2 \%+1: 200,000$ \\
\hline 18 & Oral Rehydration Salts & Powder & $\begin{array}{l}\text { Sodium chloride } 3.5 \mathrm{~g} / \mathrm{L}+ \\
\text { Trisodium citrate dihydrate } 2.9 \mathrm{~g} / \mathrm{L} \\
\text { + Potassium chloride } 1.5 \mathrm{~g} / \mathrm{L}+ \\
\text { Glucose } 20.0 \mathrm{~g} / \mathrm{L}\end{array}$ \\
\hline 19 & Artemether+ Lumefantrine & Tablet & $20 \mathrm{mg}+120 \mathrm{mg}$ \\
\hline 20 & Efavirenz + Emtricitabine + Tenofovir & Tablet & $600 \mathrm{mg}+200 \mathrm{mg}+300 \mathrm{mg}$ \\
\hline 21 & Emtrictabine + Tenofovir & Tablet & $200 \mathrm{mg}+300 \mathrm{mg}$ \\
\hline 22 & Stavudine + Lamivudine + Nevirapine & Tablet & $30 \mathrm{mg}+150 \mathrm{mg}+200 \mathrm{mg}$ \\
\hline 23 & Zidovudine + Lamivudine & Tablet & $300 \mathrm{mg}+150 \mathrm{mg}$ \\
\hline 24 & Zidovudine + Lamivudine + Nevirapine & Tablet & $300 \mathrm{mg}+150 \mathrm{mg}+200 \mathrm{mg}$ \\
\hline 25 & Medoxyprogestrone acetate +estradiol cypionate & Injection & $25 \mathrm{mg}+5 \mathrm{mg}$ \\
\hline
\end{tabular}




\section{Drug regulation in $\mathrm{Nepal}^{6}$}

Government of Nepal has promulgated the Drug Act in the year 1978 to prevent the misuse or abuse of drugs and allied pharmaceutical materials as well as the false or misleading information relating to efficacy and use of drugs. The Act also is used to regulate and control the production, marketing, distribution, export-import, storage and utilization of those drugs which are not safe for the use of people, efficacious and of standard quality,. Later on to fulfil and to implement the aim of established Drug Act 1978, the Government of Nepal established the Department of Drug Administration (DDA) in 1979. Under the Drug Act 1978, the following rules and regulation and codes have been implemented as supporting tools for the active enforcement of Drug Act 1978. However, there are no such regulations and guidelines regarding the production, marketing, distribution, export-import, storage and utilization of FDC products.

\section{Incidence of Irrational Fixed Dose Combinations use in Nepal}

Several studies indicate that Irrational Fixed Dose Combinations (IFDCs) are commonly used in Nepal. Table 2 lists some of these studies.

Table 2: Incidence of IFDCs use in Nepal

\begin{tabular}{|c|c|c|c|c|}
\hline Authors & Year of study & Study site & Incidence of FDCs & Comments \\
\hline $\begin{array}{l}\text { Chayna } \\
\text { Sarkar, et. al. }{ }^{7}\end{array}$ & $\begin{array}{l}\text { March 2001- } \\
\text { Februrary, } \\
2002\end{array}$ & $\begin{array}{l}\text { Dental outpatient } \\
\text { department at Manipal } \\
\text { Teaching Hospital } \\
\text { (MTH), Pokhara. } \\
\end{array}$ & $\begin{array}{l}\text { A total of } 38.9 \% \text { of } \\
\text { analgesics prescribed } \\
\text { were FDCs }\end{array}$ & $\begin{array}{l}\text { Most common FDC analgesic } \\
\text { was ibuprofen }+ \text { paracetamol }\end{array}$ \\
\hline $\begin{array}{l}\text { Upadhyay } \\
\text { DK, et. al. }\end{array}$ & $\begin{array}{l}\text { August 22- } \\
\text { December 7, } \\
2006\end{array}$ & $\begin{array}{l}\text { Out-patient Pharmacy } \\
\text { (OPP) at MTH, Pokhara. }\end{array}$ & $\begin{array}{l}2.34 \% \text { of the total } \\
\text { drugs were fixed-dose } \\
\text { combinations }\end{array}$ & - \\
\hline Das B, et. al. ${ }^{9}$ & $\begin{array}{l}\text { January } 1999- \\
\text { February } 2000\end{array}$ & MTH, Pokhara. & $\begin{array}{l}\text { A total of } 39.19 \% \text { drugs } \\
\text { were FDCs }\end{array}$ & $\begin{array}{l}\text { Nearly } 98 \% \text { and } 95 \% \text { of the } \\
\text { FDCs prescribed did not } \\
\text { conform to the recommended } \\
\text { Nepal and WHO lists of FDCs } \\
\text { respectively. }\end{array}$ \\
\hline $\begin{array}{l}\text { Alam K, et. } \\
\text { al. }^{2}\end{array}$ & $\begin{array}{l}\text { June } 10 \\
- \text { August 19, } \\
2004\end{array}$ & MTH, Pokhara. & $\begin{array}{l}\text { A total of } 21.67 \% \text { drugs } \\
\text { were FDCs }\end{array}$ & - \\
\hline $\begin{array}{l}\text { Joshi MP, et. } \\
\text { al. }{ }^{10}\end{array}$ & 1997 & $\begin{array}{l}\text { Medical wards of the } \\
\text { Tribhuvan University } \\
\text { Teaching Hospital } \\
\text { (TUTH), Kathmandu }\end{array}$ & $\begin{array}{l}\text { A total of } 15.4 \% \text { drugs } \\
\text { were FDCs }\end{array}$ & - \\
\hline $\begin{array}{l}\text { Rauniar, G. } \\
\text { P. }{ }^{11}\end{array}$ & $\begin{array}{l}\text { April 1998- } \\
\text { March } 1999\end{array}$ & $\begin{array}{l}\text { B.P. Koirala Institute of } \\
\text { Health Sciences, Dharan. }\end{array}$ & $\begin{array}{l}\text { Fixed dose combination } \\
\text { of ibuprofen and } \\
\text { paracetamol }(32.46 \%) \\
\text { was the most commonly } \\
\text { prescribed }\end{array}$ & - \\
\hline $\begin{array}{l}\text { Biswadeep } \\
\text { Das, et. al. }{ }^{12}\end{array}$ & 2002 & $\begin{array}{l}\text { Obstetrics out-patient } \\
\text { department (OPD) at } \\
\text { MTH, Pokhara }\end{array}$ & $\begin{array}{l}\text { A total of } 64.8 \% \text { drugs } \\
\text { prescribed were FDCs }\end{array}$ & - \\
\hline $\begin{array}{l}\text { Das BP, } \\
\text { et.al. }{ }^{13}\end{array}$ & 2001 & $\begin{array}{l}\text { Teaching District Hospital } \\
\text { of Nepal }\end{array}$ & $\begin{array}{l}\text { Fixed dose combination } \\
\text { of ampicillin and } \\
\text { cloxacillin }(12.12 \%) \\
\text { was the most commonly } \\
\text { prescribed FDC }\end{array}$ & 1- \\
\hline $\begin{array}{l}\text { Sarkar C, et. } \\
\text { al. }^{14}\end{array}$ & $\begin{array}{l}\text { March 2001- } \\
\text { February } 2002\end{array}$ & $\begin{array}{l}\text { Dental outpatient } \\
\text { departments at MTH, } \\
\text { Pokhara }\end{array}$ & $\begin{array}{l}\text { A total of } 38 \% \text { drugs } \\
\text { were FDC }\end{array}$ & - \\
\hline
\end{tabular}


Commonly used irrational fixed dose combinations in Nepal

Only 25 drug combinations out of 352 medicines in total are listed (approved) in the fifteenth WHO model list of essential medicines (March 2007). Six of these are for the treatment of HIV/AIDS and five of them are for TB. The fixed dose combinations account for $7 \%$ of the total drugs in the essential medicines list, whereas in Nepal a number of irrational drug combinations are easily available and can be bought without necessarily presenting a prescription ${ }^{6,15}$. Table 3 lists some of the commonly used IFDCs in Nepal.

Table 3: List of some commonly used IFDCs in Nepal

\begin{tabular}{|l|l|l|}
\hline \multicolumn{1}{|c|}{ Combination products } & \multicolumn{1}{|c|}{ Examples } & \multicolumn{1}{c|}{ Reasons for being termed irrational } \\
\hline $\begin{array}{l}\text { Combination of antipyretics } \\
\text { and analgesics }\end{array}$ & $\begin{array}{l}\text { Ibuprofen } 200 \mathrm{mg} \\
+ \\
\text { paracetamol } 325 \mathrm{mg}\end{array}$ & $\begin{array}{l}\text { Both these drugs have the same mechanism of } \\
\text { action. So there is no synergism. } \\
\text { NSAID combinations are known to cause } \\
\text { direct damage to kidney. }\end{array}$ \\
\hline $\begin{array}{l}\text { Combination of Codeine with } \\
\text { other medicines }\end{array}$ & $\begin{array}{l}\text { Codeine sulfate } 10 \mathrm{mg} \\
+ \\
\text { Paracetamol } 500 \mathrm{mg}\end{array}$ & $\begin{array}{l}\text { Combination can cause excessive sedation } \\
\text { which can be dangerous. Needs further } \\
\text { examination. }\end{array}$ \\
\hline $\begin{array}{l}\text { Combinations of several } \\
\text { vitamins }\end{array}$ & $\begin{array}{l}\text { Multivitamin combination is considered to be } \\
\text { irrational. Excessive use may leads to several } \\
\text { side effects. }\end{array}$ \\
\hline $\begin{array}{l}\text { Combination of ampicillin } \\
\text { Amoxycillin with } \\
\text { cloxacillin) }\end{array}$ & $\begin{array}{l}\text { Both of the combination belongs to same class } \\
\text { namely Beta lactamase acting at the same site } \\
\text { by same mechanism offering no synergism or } \\
\text { additive effects when combined. Moreover } \\
\text { combining two antibiotics acting through the } \\
\text { same mechanism cannot be justified. }\end{array}$ \\
\hline $\begin{array}{l}\text { Expectorants with central } \\
\text { cough suppressants, } \\
\text { antihistaminics, } \\
\text { bronchodilators and } \\
\text { mucolytics }\end{array}$ & $\begin{array}{l}\text { Bromhexine Hydrochloride } 8 \mathrm{mg} \\
+ \text { Terbutaline sulphate } 2.5 \mathrm{mg}+ \\
\text { Guaiphenesin } 100 \mathrm{mg}+\mathrm{Menthol} \\
5 \mathrm{mg}\end{array}$ & $\begin{array}{l}\text { Using combination of expectorants is a costlier } \\
\text { way of helping a condition which is often self- } \\
\text { resolving. } \\
\text { Expectorant given in effective doses are often } \\
\text { not tolerated and produce adverse drug reaction }\end{array}$ \\
\hline $\begin{array}{l}\text { Ayurvedic preparations } \\
\text { Arjuna }+ \text { Tharaka }\end{array}$ & $\begin{array}{l}\text { The ayurvedic preparations have no any proven } \\
\text { efficacy. }\end{array}$ \\
\hline
\end{tabular}

\section{Fixed dose combinations that are approved in National Essential Drug List (NEDL) of Nepal}

The latest version of the National Essential Drug List (NEDL) of Nepal approved only a few FDCs. These FDCs are listed in Table 4.

Table 4: Fixed dose combinations that are approved in National Essential Drug List (NEDL) of Nepal

\begin{tabular}{|c|l|l|}
\hline S. $\mathbf{N}$ & \multicolumn{1}{|c|}{ Combination } & \multicolumn{1}{c|}{ Therapeutic category } \\
\hline 1 & Levodopa + Carbidopa & Anti parkinsonism \\
\hline 2 & Isoniazid + Rifampicin & Antitubercular \\
\hline 3 & Isoniazid + Ethambutol & Antitubercular \\
\hline 4 & Thiacetazone + Isoniazid & Antitubercular \\
\hline 5 & Sulfamethoxazole+ Trimethoprim & Antibacterial \\
\hline 6 & Benzoic acid+ salicylic acid & Antifungal \\
\hline 7 & Ferrous salt+ folic acid & Antianaemic \\
\hline 8 & Ichtammol (10\%)+ Glycerine 5\% & Antiseptic \\
\hline 9 & Aluminium Hydroxide + Magnesium Hydroxide & Antacid \\
\hline 10 & Sulfadoxine+ Pyrimethamine & Antimalarial \\
\hline 11 & Tannic acid+ Glycerine & Antiseptic \\
\hline
\end{tabular}




\section{Consequences of fixed dose combinations}

There are several consequences due to the use of FDCs. Some of these are listed below.

1. FDCs may lead to an ineffective dosage. In certain cases like heart failure, it becomes necessary to determine the strength of the dose against the appropriate end point. It is better to handle individual drugs rather than combinations in such life threatening conditions ${ }^{3}$. Avoiding unnecessary FDCs may help in reducing prescribing costs because FDCs usually cost more than single ingredient preparations ${ }^{7}$.

2. A combination makes it more difficult to pinpoint the offending agent responsible for the adverse reaction.; The greater the number of ingredients, the less likely the prescriber or the physician will know what the active ingredients are and what are their adverse reactions.. This has been witnessed with analgesic mixtures in the past, which contained Phenacetin along with aspirin and caffeine (APC) Tablets. The drug Phenacetin has now been banned as it causes renal disease ${ }^{1}$.

3. Some FDCs lead to abuse. For example, drug dependence of dextropropoxyphene leads to accidental or intentional over dosage. Patients using combination products often overdose with dextropropoxyphene as a complication ${ }^{1}$.

4. FDCs increase the cost of therapy. Concerning the non-economic, long-term costs of the use of FDCs rather than single-ingredient drugs, one finds that FDCs cause more harm than good in the long run. Adverse drug reactions and drug interactions are more frequent with FDCs. These reactions and interactions are potentially debilitating and can increase the duration of illness as well as the cost of therapy with FDCs.

5. Drug resistance; A more serious concern regarding the use of IFDCs is the emergence of drug resistance to several antibiotics from inappropriate prescription.

Interventions to minimize irrational fixed dose combinations

Some interventions that can be carried out to minimize IFDCs are as follows:

Educational interventions: Awareness programs with focus on the deleterious consequences related to the irrational use of medicines should be carried out. All health care professionals should be made aware about the hazards of IFDCs. Educational interventions to improve prescribing for doctors at different levels may be required. Educational sessions, especially for the junior doctors on the impacts of IFDCs should be organized. Mass awareness and education are critical to reduce this trend. Non-governmental organizations can play a role. Doctors prescribing FDCs without diagnostic tests are indulging in a significant violation of treatment ethics because they are ignoring the possibilities of harm to the patient from unnecessary medication as well as the long-term public health consequences of such prescriptions. There is a need to strengthen the mechanism for continuing professional development of practitioners to ensure that they have the necessary knowledge and skills to prescribe rationally.

Managerial interventions: The percentage of drugs prescribed from the essential drug list of Nepal is low. The reason may be related to lack of awareness about the essential drug concept and essential drug list among prescribers. Use of Nepalese National Formulary(NNF) and WHO model formulary should be encouraged. Prescribing from these formularies can reduce the number of irrational combinations entering the market. It can also reduce the cost spent on drugs. Similarly regular updating of the NNF is also required.

Regulatory interventions: Several literature surveys indicate that the amount of drugs prescribed from the essential drug lists was low. Though the essential drug list was mainly developed for primary health care facilities, prescription of essential drugs should be encouraged. Efforts should be made to develop a hospital formulary based on the concept of essential medicines. Drugs should be prescribed only when genuinely indicated. Similarly the use of FDCs should be discouraged. Guidelines should be developed on the production, sale-distribution and export-import of irrational fixed dose combination products. Direct to consumers advertisements of such drug combinations should also be discouraged and manufacturers should also do adequate research on the rationality of drug combinations before producing and marketing them.

\section{Interventions done in Nepal in relation to fixed dose combinations}

The DDA had banned several combination products based on their risk and adverse effects. Banned drug list of DDA includes several combination products. Some of them are listed in Table 5. 
Table 5: List of some banned FDC products in Nepal

\begin{tabular}{|c|l|c|}
\hline SNo. & \multicolumn{1}{|c|}{ Banned FDC } & Year of banning \\
\hline 1 & Combination of vitamins with tranquilisers and / or anti-inflammatory agents & 1984 \\
\hline 2 & Combinations of antihistamines with antidiarrhoels or with antiamoebic drugs. & 1984 \\
\hline 3 & Combinations of vitamins C with tetracycline. & 1984 \\
\hline 4 & Combinations of vitamins with analgesics. & 1984 \\
\hline 5 & Amphetamine and its Combinations. & 1991 \\
\hline 6 & Phenformin and its Combinations. & 1991 \\
\hline 7 & Sulphaguanidine and its Combinations. & 1991 \\
\hline 8 & Phenylbutazone in Combination with other Drugs & 1991 \\
\hline
\end{tabular}

\section{Intervention done in Manipal Teaching Hospital on FDCs}

Drug and Therapeutic committee in Manipal Teaching Hospital regulates the activities related to drug use in the hospital. The DTC is also playing an active role in controlling the irrational combinations of drugs in the hospital. In the year 2005 the committee banned the use of fixed dose combination of Amoxicillin and Cloxacillin, and Ampicillin and Cloxacillin in the hospital. Similarly the DTC has also banned several multivitamins and B-complex preparations containing multiple combinations ${ }^{17}$.

\section{Conclusion}

Rational combinations can be of immense help to the health care system. These combinations may improve the quality of life for many people. Such combinations (for example, antitubercular and antiretroviral combinations) are used frequently for many diseases ${ }^{18}$. However the irrational fixed dose combination products are considered to be equally harmful.

According to the WHO Expert Committee, combination drugs should only be used when there are no alternative of single drugs available for treatment or no alternative single drug is cost-effective for the purpose. Combination drugs increase the risk of side effects and may also needlessly increase the cost. Combination drugs are irrational also because their stability is doubtful, reducing the efficacy of many preparations ${ }^{16}$. The analysis of reports received by pharmacovigilance centres show that the common reason for adverse drug reactions is irrational use of medicines ${ }^{19}$. One of the main cause of irrational use of medicines may be availability of irrational fixed dose combinations.

Most essential drugs should be formulated as single compounds. Fixed dose ratio combination products are acceptable only when the dosage of each ingredient meets the requirements of a defined population group and when the combination has a proven advantage over single compounds administered separately in therapeutic effects, safety or compliance ${ }^{20}$.

\section{References}

1. Avijit C. Fixed dose combinations in therapyExpress Pharma. India; Indian Express Newspapers Limited [updated 2007 August 15; cited 2008 February 25]. Available from: http:// www.expresspharmaonline.com/20070815/ research02.shtml.

2. Alam K, Mishra P, Prabhu MM, Shankar PR, Subish P, Bhandari RB, Bista D. A study on rational drug prescribing and dispensing among outpatients in a tertiary care teaching hospital of Western Nepal. Kathmandu Univ Med J. 2006; 15: 436-44.

3. Pradeep DT, Purohit S. Rationality of Fixed Dose Combinations: Necessity to weed out the Irrational Combinations Mushrooming in Pharmaceutical Industry. India; Pharmacinfo. net [updated 2008 January 20; cited 2008 March 1]. Available from: http://www.pharmainfo.net/ reviews/rationality-fixed-dose-combinationsnecessity-weed-out-irrational-combinations

4. WHO Expert Committee on Specifications for Pharmaceutical Preparations. WHO Technical Report Series - 929 (39 $9^{\text {th }}$ Report, 2005) [cited 2008 January 20]

5. World Health Organization (WHO) Model List of Essential Medicines $15^{\text {th }}$ List, March 2007 [cited 2008 February 27]. Available from: http://www.who.int/medicines/publications/ essentialmedicines/en/index.html

6. Official website of the department of drug administration. Nepal: Department of Drug Administration [cited 2008 February]. Available from: http://www.dda.gov.np/background.php

7. Sarkar C, Das B, Baral P. Analgesic use in dentistry in a tertiary hospital in western Nepal. Pharmacoepidemiol Drug Saf. 2004; 13: 729 -3.

8. Upadhyay DK, Palaian S, Ravi Shankar P, Mishra P, Sah AK. Prescribing pattern in diabetic outpatients in a tertiary care teaching hospital in Nepal. Journal of Clinical and Diagnostic Research. 2007; 1: 248-55. 
9. Das B. Prescribing trend of fixed-dose drug combinations in a tertiary hospital in Nepal. J Inst Med. 2000; 22.

10. Joshi MP, Sugimoto T, Santoso B. Geriatric prescribing in the medical wards of a teaching hospital in Nepal. Pharmacoepidemiol Drug Saf. 1997;6:417-21.

11. Rauniar GP, Naga RMA, Das BP, Agrawal CS. Analgesic utilization in postoperative care at a tertiary care teaching hospital in Nepal. J Nepal Med Assoc. 2003; 42: 148-50.

12. Das B, Sarkar C, Datta A, Bohra S. A study of drug use during pregnancy in a teaching hospital in western Nepal. Pharmacoepidemiol Drug Saf. 2003; 12(3): 221 -5.

13. Das BP, Sethi A, Rauniar GP. Antimicrobial utilization pattern in a teaching District Hospital of Nepal. JNMA J Nepal Med Assoc. 2004; 43: 119-24.

14. Sarkar C, Das B, Baral P. An audit of drug prescribing practices of dentists. Indian J Dent Res. 2004; 15: 58-61.
15. Gautam CS, Aditya S. Irrational drug combinations: Need to sensitize undergraduates. Indian J Pharmacol.. 2006; 38: 169-70.

16. Rationality of drugs. India; [cited 2008 February 12]. Available from http://www.locostindia. com/CHAPTER_3/Rationality\%20of\%20 Drugs.htm.

17. Mishra P, Alurkar VM, Subish P. Functions of a drug and therapeutics committee in Nepal. J Pharm Pract Res. 2006; 31: 81.

18. Prakash S. Irrational combinations: No consideration for patient safety. Indian $\mathrm{J}$ Pharmacol. 2007; 39: 217.

19. Woroń J, Porebski G, Kostka-Trabka E, Goszcz A. Irrational use of drugs as a source of drug - induced diseases. Med Wieku Rozwoj. 2007; 11: 87-91.

20. The Use of Essential Drugs. WHO Technical Report Series 825. Geneva. World Health Organization, 1992. 